\title{
Perilaku konsumtif sebagai dampak online shop di kalangan mahasiswa Sosiologi 2019 Universitas Negeri Malang
}

\author{
Catur Dian Rahayu, Hasna Bararah M, Kalya Nabila Zuhdi, Muhammad Iqbal Perdana, \\ Nabilah Fina Aprilia, Pramana Herjati Putra Dionchi, Ananda Dwita Yuniar* \\ Universitas Negeri Malang, Jl. Semarang No. 5 Malang, Jawa Timur, Indonesia \\ *Penulis korespondensi, Surel: ananda.dwita.fis@um.ac.id
}

Paper received: 01-05-2021; revised: 15-05-2021; accepted: 30-05-2021

\begin{abstract}
The presence of technology brings about a change in people's lives, with technology of all activities being more comfortable. Technological changes have taken place in the field of digital marketing, such as shopping online. The presence of an online shop provides considerable comfort in shopping activities. But with that convenience, it can also establish higher consumption patterns. This consumption pattern was analyzed using the concept of the consumption of Jean Boudrilland. The study USES a descriptive qualitative approach with the data-collection technique of structured interviews. In the study two results have been found, the first of these is consensual behaviors among sociology students where they buy goods through online shops out of sheer need. The second result was that a sociology student was seeking to remain unaffected by the ease of shopping through online shops in order to avoid the form of consumer behavior. From such exposure it can be concluded that the concept of consumptive society by Jean Boudrilland is relevant to today's lives where people tend to satisfy the urge to buy things instead of the need.
\end{abstract}

Keywords: online shop; consumer behavior; consumer society

\begin{abstract}
Abstrak
Kehadiran teknologi membawa perubahan dalam kehidupan masyarakat, dengan adanya teknologi segala aktivitas dapat dilakukan dengan lebih nyaman. perubahan karena teknologi turut hadir dalam bidang digital marketing seperti hadirnya online shop. Kehadiran online shop cukup memberikan kenyamanan dalam aktivitas belanja. Namun dengan kenyamanan tersebut dapat pula membentuk pola konsumsi yang semakin tinggi. Pola konsumsi ini dianalisis menggunakan konsep masyarakat konsumsi dari Jean Boudrilland. Penelitian ini menggunakan metode pendekatan kualitatif deskriptif dengan teknik pengumpulan data yakni wawancara terstruktur. Dalam penelitian ini ditemukan dua hasil, yang pertama adanya perilaku konsumtif di kalangan mahasiswa sosiologi dimana mereka membeli barang melalui online shop karena keinginan bukan kebutuhan. Hasil yang kedua yakni ditemukan adanya mahasiswa Sosiologi yang berusaha untuk tidak terpengaruh kemudahan berbelanja melalui online shop dengan tujuan agar tidak terbentuk perilaku konsumtif. Dari pemaparan tersebut dapat disimpulkan bahwa konsep masyarakat konsumtif oleh Jean Baudrillard relevan dengan kehidupan saat ini dimana masyarakat cenderung memuaskan keinginan membeli suatu barang bukan atas dasar kebutuhan.
\end{abstract}

Kata kunci: online shop; perilaku konsumtif; masyarakat konsumsi

\section{Pendahuluan}

Dengan adanya kemajuan teknologi 4.0, turut serta membawa perubahan pada tiap aspek kehidupan. Segala aktivitas dibantu dan dimudahkan dengan adanya pergerakan perubahan menggunakan sistem online. Sistem online dapat dengan mudah dan cepat diterima oleh masyarakat karena menawarkan bentuk kepraktisan dan keefisienan. Beberapa contoh yang banyak dipengaruhi oleh perkembangan teknologi yaitu komunikasi, informasi dan industri. Hal tersebut yang menyebabkan kondisi masyarakat sosial turut serta mengikuti 
perubahan yang terjadi. Salah satu perubahan yang terjadi adalah perubahan di bidang digital marketing seperti online shop.

Online shop atau belanja online merupakan proses kegiatan jual beli melalui internet tanpa adanya tatap muka. Hingga saat ini, banyak pilihan online shop yang tersedia, beberapa diantaranya sudah menguasai pasar industri, seperti Shopee, Tokopedia, Lazada, Bukalapak, JD.id, Zalora, dll. Online shop membuat proses jual beli menjadi mudah dan praktis. Online shop saat ini tidak hanya dipandang sebagai pilihan dalam kegiatan berbelanja namun juga menjadi aspek perubahan sosial budaya khususnya dalam masyarakat (Sari, 2015). Online shop diperkenalkan kepada masyarakat pada tahun 1994, yang lebih dikenal dengan istilah yang merupakan singkatan dari electronic commerce. merupakan penggunaan teknologi melalui internet dalam proses transaksi bisnis terkait dengan kegiatan jual beli. Dari inilah kegiatan jual beli berkembang menjadi jual beli online. Pengguna online shop berasal dari berbagai kalangan namun, mayoritas pengguna online shop adalah mahasiswa. Mahasiswa merupakan kaum muda yang memahami kemajuan teknologi dan cukup aktif menggunakan jejaring sosial sehingga rentan terbuai dengan kemudahan belanja yang diajukan online shop. Kemudahan belanja di online shop membuat pola konsumsi mahasiswa semakin tinggi. Pola konsumsi yang semakin tinggi ini dapat memberikan dampak negatif seperti perilaku konsumtif.

Perilaku konsumtif merupakan suatu tindakan membeli suatu barang tanpa mempertimbangkan faktor kebutuhan yang masuk akal (Sumartono, 2002). Perilaku konsumtif membuat mahasiswa membeli barang yang diinginkannya, bukan barang yang dibutuhkannya. Terbentuknya perilaku konsumtif membuat mahasiswa tidak bisa mengontrol pengeluaran yang meningkat. Melalui permasalahan tersebut mahasiswa membutuhkan selfcontrol, sehingga dapat menahan dan mengurangi perilaku kecenderungan membeli barang tanpa pertimbangan.

Penelitian ini menggunakan konsep masyarakat konsumsi dari Jean Boudrilland. Menurut Baudrilland masyarakat konsumsi merupakan masyarakat yang mengkonsumsi barang melalui keindahannya bukan pada kegunaannya, sehingga masyarakat tidak akan pernah puas dan mendatangkan rasa ingin mengonsumsi lagi dan lagi. Masyarakat indonesia saat ini cenderung menjadi masyarakat konsumsi. Hal ini dapat diketahui melalui gaya berpakaiannya dan barang yang digunakannya yang seringkali mengikuti mode yang menjadi tren. Melalui permasalahan yang telah dipaparkan, tujuan dari penelitian ini adalah mengetahui perilaku konsumtif yang terbentuk di kalangan mahasiswa sosiologi angkatan 2019 Universitas Negeri Malang sebagai dampak dari adanya online shop.

\section{Metode}

Penelitian ini menggunakan metode pendekatan kualitatif deskriptif. Pendekatan kualitatif deskriptif yaitu penelitian yang mendeskripsikan serta menginterpretasi hubungan, pendapat, proses, serta akibat dari permasalahan yang diambil. Kami berusaha menggambarkan objek penelitian sebagaimana perilaku konsumtif dari dampak adanya online shop sesuai fakta yang ada di lapangan. Penelitian kualitatif ini dapat menemukan, menyelidiki, menggambarkan, serta menjelaskan dengan rinci kasus permasalahan dilapangan yang tidak dapat diukur melalui penelitian kuantitatif.

Penelitian ini menggunakan teknik pengumpulan data wawancara terstruktur. Kami melakukan wawancara secara tatap muka dan menggunakan online chat via aplikasi WhatsApp. Dalam hal ini, kami mencari informan di lingkungan mahasiswa jurusan sosiologi 
Universitas Negeri Malang berdasarkan kriteria yang telah ditentukan dan sesuai dengan masalah dan tujuan penelitian. Kami mencari informan yang biasa dan sering menggunakan online shop untuk berbelanja. Dalam pendekatan deskriptif, hasil dari wawancara dijabarkan sesuai dengan pernyataan informan, sehingga penelitian ini sendiri tidak hanya mengacu pada subjektivitas peneliti. Fokus penelitian kami adalah perubahan perilaku karena budaya konsumtif di kalangan mahasiswa dalam pesatnya perkembangan di Indonesia.

\section{Hasil dan Pembahasan}

Semakin pesatnya perkembangan teknologi dan semakin mudahnya akses internet, membuka peluang bagi masyarakat untuk melakukan kegiatan jual beli secara online, akibatnya kini marak bermunculan aplikasi-aplikasi jual beli online seperti Tokopedia, Shopee, Bukalapak dan lain sebagainya. Kehadiran banyak online shop sendiri banyak menuai pro dan kontra, jual beli secara online memang dianggap mampu memberikan banyak keuntungan khususnya dalam segi kepraktisan, pembeli tak harus lagi datang ke toko dan antri untuk pembayaran di kasir, oleh karena itu mereka merasa dimudahkan oleh hadirnya berbagai macam online shop, disamping kemudahan yang dirasa oleh para customer, online shop membawa dampak lain bagi masyarakat kita seperti munculnya budaya konsumerisme. Konsumerisme muncul seiring dengan meningkatnya ketertarikan masyarakat terhadap perubahan dan inovasi, sebagai respon terhadap penanggulangan yang cepat dari hal-hal yang baru.

Kami telah mengajukan beberapa pertanyaan kepada sejumlah informan yang akan menjadi hasil dari penelitian kami. Kami memilih informan dengan kriteria yang kita telah tentukan. Kriteria yang kami tentukan dalam memilih informan kami adalah mahasiswa jurusan Sosiologi Universitas Negeri Malang angkatan 2019 yang sering melakukan transaksi belanja di online shop. Berdasarkan temuan data, kini online shop telah merambah ke berbagai kalangan masyarakat, tak hanya para pemilik usaha dan ibu rumah tangga saja yang menerima dampak dari online shop, kini online shop sudah menjamur di kalangan anak muda terutama mahasiswa. RA, salah satu informan kami mengungkapkan bahwa ia termasuk pengguna online shop, ia sering membeli barang-barang kebutuhannya di online shop, tak hanya barang kebutuhannya, ia mengatakan lebih menyukai membeli barang yang diinginkannya daripada yang dibutuhkan. Selain RA, informan kami YD juga mengungkapkan hal yang sama. Barang yang mereka beli merupakan barang yang menurut mereka menarik dan tentu saja murah. Akhir-akhir ini online shop memang sedang gencar-gencarnya memberikan berbagai macam diskon dan gratis ongkos kirim untuk beberapa item yang dijualnya, faktor itulah yang mendorong masyarakat lebih menyukai berbelanja online daripada langsung datang ke toko.

Berdasarkan temuan data, informan kami mengungkapkan tidak memiliki waktu khusus saat berbelanja online, hanya saja saat mereka ingin dan memiliki waktu luang baru mereka melihat barang-barang online shop, selain itu munculnya iklan-iklan di beranda mereka membuat mereka semakin tertarik untuk berbelanja online, daya tarik lainnya yang membuat mereka gemar berbelanja di online shop karena stok barang yang bervariatif dan unik, saat mereka tidak menjumpai barang yang mereka inginkan di toko A, mereka bisa langsung beralih ke toko B atau ke toko C. Informan kami mengungkapkan sendiri bahwa dengan hadirnya berbagai kemudahan dan kenyaman yang ditawarkan oleh online shop membuat mereka hidup lebih konsumtif. Pengaruh perkembangan online shop akhir-akhir ini memang tak bisa dibendung lagi, sikap konsumtif semakin ditunjukkan oleh masyarakat Indonesia, mereka 
merasa bangga dengan mampu membeli barang-barang yang sedang trend saat ini, tanpa melihat nilai guna mereka rela menghambur-hamburkan uangnya untuk kepuasan dirinya.

Ada juga hasil dan kesimpulan yang kami temukan yaitu tentang penerimaan dan penolakan terhadap adanya online shop. Dalam era digital ini penggunaan internet dalam berbagai bidang sangat dibutuhkan. Keadaan ini dimanfaatkan oleh pengusaha dengan membentuk dalam memasarkan produknya melalui online shop. Mayoritas informan menyukai adanya online shop karena lebih praktis dan efisien. Informan berpendapat bahwa dengan adanya online shop dapat mempermudah dalam kegiatan jual beli karena hanya menunggu barang datang dan tidak perlu pergi ke toko. Online shop memberikan dampak yang positif pada era masa kini. Keunggulan yang disajikan online shop memberikan kepuasan kepada konsumen. Adanya promo, cashback dan potongan harga yang ditawarkan kepada konsumen menjadikan daya tarik bagi konsumen untuk berlangganan online shop.

Daya tarik yang diberikan oleh online shop membuat ketertarikan bagi konsumen untuk terus berbelanja. Hal ini dapat menimbulkan perilaku konsumtif pada konsumen. Perilaku konsumtif merupakan tindakan membeli barang tanpa mempertimbangkan kebutuhan dan cenderung membeli barang yang diinginkan saja (Sumartono, 2002). Timbulnya perilaku konsumtif harus diimbangi dengan self control. Self control adalah bentuk kemampuan individu dalam menghambat dorongan yang ada. Adanya self control dapat membatasi konsumen untuk tidak membeli barang yang diinginkan tetapi mendorong konsumen untuk membeli barang yang dibutuhkan.

Selain informan yang terpengaruh adanya online shop, ada pula informan yang tidak terpengaruh adanya online shop. Informan yang tidak terpengaruh dengan adanya online shop didasarkan kepada perilaku konsumtif yang dapat timbul karena adanya online shop. Informan berusaha untuk tidak terpengaruh terhadap segala aspek seperti kemudahan berbelanja, diskon, maupun promosi dalam online shop. Informan berpendapat bahwa adanya online shop dapat menyebabkan terbentuknya perilaku konsumtif. Adanya online shop membuat konsumen tertarik untuk sering berbelanja. Ketertarikan berbelanja membentuk perilaku konsumtif dalam diri konsumen. Menurut pandangan informan berbelanja secara langsung merupakan kegiatan yang lebih positif.

\section{Simpulan}

Dari hasil yang telah kita peroleh, menunjukkan bahwa perilaku yang dilakukan oleh mahasiswa dalam menghadapi fenomena online shop pada perkembangan di Indonesia saat ini relevan dengan teori masyarakat konsumsi milik Jean Baudrillard. Menurut Jean Baudrillard, masyarakat di masa modern ini sudah memasuki pergeseran konsep konsumsi, hal ini sejalan dengan perilaku konsumtif yang hakekatnya membeli barang yang diinginkan, alih-alih mempertimbangkan kebutuhannya. Modern ini, perilaku konsumtif sudah melekat terhitung sejak online shop mulai mengembangkan eksistensinya (Azwar, 2014). Dengan banyaknya pilihan dan penawaran yang menjanjikan dari online shop, mereka tidak akan pernah puas memanjakan keinginannya untuk terus mengikuti tren. Sehingga membuat perilaku konsumtif itu sulit untuk dikendalikan.

\section{Daftar Rujukan}

Azwar, M. (2014). Teori Simulakrum Jean Baudrillard dan upaya pustakawan mengidentifikasi informasi realitas. Khizanah al-Hikmah: Jurnal Ilmu Perpustakaan, Informasi, dan Kearsipan, 2(1), 38-48. 
Jurnal Integrasi dan Harmoni Inovatif Ilmu-Ilmu Sosial, 1(5), 2021, 542-546

Sari, C. A. (2015). Perilaku berbelanja online di kalangan mahasiswi antropologi Universitas Airlangga (Doctoral dissertation, UNIVERSITAS AIRLANGGA).

Sumartono, \& Djabar, H. B. (2002). Terperangkap dalam iklan: Meneropong imbas pesan iklan televisi. Alfabeta.

Gumulya, J., \& Widiastuti, M. (2013). Pengaruh konsep diri terhadap perilaku konsumtif mahasiswa Universitas Esa Unggul. Jurnal Psikologi Esa Unggul, 11(01), 126900.

Miranda, S., \& Lubis, E. E. (2017). Pengaruh instagram sebagai media online shopping fashion terhadap perilaku konsumtif mahasiswi Fakultas Ilmu Sosial Dan Ilmu Politik Universitas Riau (Doctoral dissertation, Riau University). 